International Journal of Agriculture and Environmental Research

ISSN: 2455-6939

Volume: 07, Issue: 03 "May-June 2021"

\title{
THE IMPACT OF BIOFERTILIZERS AND CHEMICAL FERTILIZERS ON TWO GROUNDNUT CULTIVARS PRODUCTIVITY UNDER THE SEMI-ARID TROPICS OF SUDAN
}

\author{
A. B. Elgazali ${ }^{1}$, M. A. $\operatorname{Hadad}^{2}$, A. M. Mirghani ${ }^{3}$, M. D. Haron ${ }^{4}$ \\ ${ }^{1}$ Post Graduate Student, College of Agricultural Studies, SUST, Sudan \\ ${ }^{2}$ Professor of Soil Microbiology, College of Agricultural Studies, SUST, Sudan \\ ${ }^{3}$ Assistant Professor of Soil Microbiology, College of Agricultural Studies, SUST, Sudan \\ ${ }^{4}$ Yangzhou University College of Agricultural, China, Africa City of Technology, Sudan \\ DOI: https://doi.org/10.51193/IJAER.2021.7308
}

\begin{abstract}
Two groundnut cultivars treated with Rhizobium strain with two concentrations and isolated local Mycorrhiza fungi chosen for this study compared with chemical fertilizers. The strains were screened in pots at the College of Agricultural Studies, Sudan University of Science and Technology. The study was performed to investigate the effects of Rhizobium strains and isolated local Mycorrhizal fungi from sorghum rhizosphere on groundnut plant in terms of (plant height, top dry weight, colour rating, nodulation, yield and tissue content of nitrogen, potassium and phosphorus). The performance of the combination between Mycorrhiza fungi and Rhizobium strain enhanced and developed the growth of groundnut plants. The performance of the Mycorrhiza fungi alone enhanced the groundnut plant on nutrient uptake and plant and over the inoculated plants and control. Rhizobium positively affected groundnut the plant growth traits and nutrient uptake; The performance of urea fertilizer enhanced the plant weight of groundnut M383 cultivar, also affected by the addition of Rhizobium bacteria as a single treatment and the Mycorrhiza fungi in all measurements. The Ahmadi cultivar was also affected by the treatment of Rhizobium bacteria in the yield, number and weight of root nodules.
\end{abstract}

Keywords: Biofrtilizer, Chemical fertilizer, Groundnut, Rhizobium, Mycorrhiza.

\section{INTRODUCTION}

Groundnuts (Arachis hypogaea) family leguminaceae, also known as peanuts or monkey nuts, are the edible seeds of a legume plant that grow to maturity in the ground. The crop is cultivated 
International Journal of Agriculture and Environmental Research

ISSN: 2455-6939

Volume: 07, Issue: 03 "May-June 2021"

in nearly 100 countries, over $90 \%$ of developing countries; the groundnut is a food staple and valuable cash crop for millions of households (Ahmed et al., 2020). It is the $13^{\text {th }}$ most essential food crop and the 4th most crucial oilseed crop (Taru et al., 2010). Due to the Sudanese soil problem, which is represented in the deficiency of macro element (Nitrogen, Phosphorus and Potassium) and some of the microelements, the immediate solution is to use organic and biofertilizers that can repair and fix the problems and in the same way do not deplete of natural resources.(Osman and Abd Elaziz, 2010). Biofertilizers are means of fixing and availability the nutrients in the soil. Involved microorganisms could readily and safely convert complex organic material into simple components, so that they are easily taken up by the plants. Microorganism function is continuous in long duration, causing improvement of the soil fertility. It maintains the natural habitat of the soil. Crops versus control groups (Htwe et al., 2019). Biofertilizers increase crop yield by $20-30 \%$, replaces chemical nitrogen and phosphorus by $30 \%$, and stimulates plant growth. It can also provide protection against drought and some soil-borne diseases. It has also been shown that produce a larger quantity of crops, biofertilizers with the ability of nitrogen fixation and phosphorus solubilizing would lead to the greatest possible effect in plant growth. (Schütz et al., 2018). Nitrogen is the most important element in the growth and development of plants (Albareda et al., 2009). Ecofriendly $\mathrm{N}_{2}$ fixing microorganisms inhabitant to Sudanese soils; Biological nitrogen fixation is anessential process that promotes plant growth and increases its productivity could be symbiotic or non-symbiotic according to the relationship between plant and bacteria. (Kızlkaya, 2008). Phosphorus is basically necessary for healthy growth with the effectual root system and profuse nodulation which can then impact the $\mathrm{N}_{2}$ fixation potential (Amba et al., 2013). Research work by (Mmbaga et al., 2014) reveals that legumes inoculated with Rhizobium in addition to phosphorus fertilizer respond differently in terms of growth, yield and nitrogen fixation. Also (Ahiabor et al., 2014) observed that combined application of phosphorus at $45 \mathrm{~kg} \mathrm{P}$ ha-1 plus Rhizobium inoculants increased nodulation by $56 \%$ and recorded significant groundnut grain yields. Adding mycorrhiza inoculums to the Sudanese soils, which are helpful to solve Phosphorus deficiency, also the availability of indigenous Mycorrhiza in the rhizosphere of most crops of economic importance such as sorghum and groundnuts needs thorough investigations. The degree of damage caused by the weeds has been a function of their leaf area index (LAI) compared to their competing crop.(El Naim and Ahmed, 2010), (M.M., A., Hadad, M. A., \& Elhassan, 2016). Investigations in Sudan showed that plant inoculated with mycorrhizal fungi increased dry matter, phosphorus and nitrogen content, and in case of legumes better nodulation and nitrogen fixation (Howieson and Ballard, 2004). Experment was conducted in Sudan AM fungi and Rhizobium positively affected groundnuts plant growth traits and nutrient. The performance of the AMF alone or in combinations with Rhizobium strains was significantly better than that of the bacteria alone in terms of plant height, top dry weight and 
root dry weight (M.M., A., Hadad, M. A., \& Elhassan, 2016). Therefore, this work was conducted to achieve the following objectives:

- To increase groundnut yield by adding different kinds of fertilizers. And Rhizobium added as a biofertilizer.

- To isolate local Mycorrhiza fungi from the rhizosphere of sorghum plant and add them as a biofertilizer. and to measure the response of the growth of two cultivars of groundnut to biofertilizers and chemical fertilizers.

\section{MATERIALS AND METHODS}

\section{In vitro study:}

\section{Isolation of Mycorrhiza spores:}

The spores were isolated by wet sieving and transferring method (Gerdemann and Nicolson, 1963) with the following modifications; Fifty grams of demonstrative soil sample were drawn from each site and suspended in $1000 \mathrm{ml}$ of tap water and stirred thoroughly. The suspension was allowed to stand for 15 minutes and then passed complete a series of sieves $1 \mathrm{~mm}$ size, $500 \mu \mathrm{m}, 250 \mu \mathrm{m}, 125 \mu \mathrm{m}, 53 \mu \mathrm{m}$ and $45 \mu \mathrm{m}$ arranged in descending order of their mesh size. The spores on the six sieves were transferred to a $250 \mathrm{ml}$ conical flask.

\section{Rhizobium strains:}

The Rhizobium strain was isolated from groundnut nodules in the Northern State of Sudan. Erlenmeyer flasks containing $200 \mathrm{ml}$ of sterile medium yeast extract mannitol agar (YEMA) were inoculated with the Rhizobium strain under aseptic conditions. The flasks were placed on an orbital shaker at $200 \mathrm{rpm}$ at ambient temperature for seven days. (Howieson and Ballard, 2004). Serial dilutions were made to count the Rhizobium cells $/ \mathrm{ml}$.

\section{In vivo study:}

\section{General description of the experimental site:}

The experiment was done in a rainy season in July 2019 at the experimental field, the College of Agricultural Studies, Sudan University of Science and Technology, in shambat, Khartoum, North.

\section{Samples collection:}

Soil and root samples from plants (groundnut and sorghum) were collected from the rhizosphere from $0-30 \mathrm{~cm}$ depth of two different sites of Sudan; Northern State and Khartoum state. 


\section{Treatments:}

The treatments applied as follows: control, nitrogen mineral fertilizer (Urea), Rhizobium inoculums $\left(10^{4}\right)$, Rhizobium inoculum $\left(10^{8}\right)$, phosphorus mineral fertilizer (Superphosphate), the mixture of nitrogen mineral fertilizer(Urea)+ phosphorus mineral fertilizer ( Superphosphate), the mixture of mycorrhizal spores + Rhizobium inoculum $\left(10^{4}\right)$, mycorrhizal spores + Rhizobium inoculum $\left(10^{8}\right)$ and mycorrhizal spores.

\section{Seeds:}

The seeds of groundnut, Ahmadi variety, and M383 variety used in this work were obtained from The Agricultural Research Corporation (Shambat Station). The seeds were sterilized with $\mathrm{H}_{2} \mathrm{O}_{2}$ (3\%) for 15 minutes.

\section{Seeds inoculation:}

The seeds were mixed with the inoculum after germinating them in the incubator before putting them in the pots.

\section{Plant samples:}

The samples from each pot were taken randomly after one month, two months and four months.

\section{Tissue analysis:}

Nitrogen content determined using the Kjeldahl method; Phosphorus was determined using a Spectrophotometer, and potassium determined using a Flame photometer (Ryan et al., 1996).

\section{Statistical analysis:}

A completely randomized design was used with 9 replicates. Statistical analysis was conducted using (MSTAT) program. Mean separation was done using Duncan multiple range tests (Harter, 1960).

\section{RESULTS AND DISCUSSIONS}

\section{In Vivo Study (Pot experiment):}

\section{Ahmadi cultivar:}

Effect of treatments on plant height and colour rating. 
Table (1) showed that AM fungi and Rhizobium positively affected groundnuts plant height in the pots. Furthermore, the fungi in combinations with Rhizobium strains were significantly better than that of the bacteria alone in plant height, matching with (M.M., A., Hadad, M. A., \& Elhassan, 2016) and (Mmbaga et al., 2014). The highest value of colour rating was observed with plants inoculated with a combination between Mycorrhiza and Rhizobium $10^{4}$. The combination between Mycorrhiza and Rhizobium $10^{8}$ and minerals added and treatment of superphosphate recommended dose.

Table 1: Effect of treatments on plant height and colour rating

\begin{tabular}{|c|c|c|c|c|c|c|}
\hline \multirow{2}{*}{$\begin{array}{c}\text { Ahmadi } \\
\text { Treatments }\end{array}$} & \multicolumn{3}{|c|}{ Plant height cm/plant } & \multicolumn{3}{|c|}{ Colour rating } \\
\hline & (1) Month & (2) Month & (3) Month & (1) Month & (2) Month & $\begin{array}{c}\text { (3) } \\
\text { Month }\end{array}$ \\
\hline Urea & $\mathbf{1 7 . 8 3}^{\mathrm{b}}$ & $24.73^{c}$ & $29.00^{\mathrm{bc}}$ & $\mathbf{3 . 0 0 0}^{\mathrm{abc}}$ & $2.000^{b}$ & $2.000^{b}$ \\
\hline Rhizobium $10^{4}$ & $19.93^{a b}$ & $25.67^{c}$ & $33.20^{a b}$ & $3.667^{\mathrm{a}}$ & $2.333^{a b}$ & $2.000^{\mathrm{b}}$ \\
\hline Rhizobium $10^{8}$ & $20.17^{\mathrm{ab}}$ & $\mathbf{3 1 . 3 3}^{\mathrm{ab}}$ & $\mathbf{3 5 . 3 3}^{\mathrm{a}}$ & $3.000^{\text {abc }}$ & $2.3^{2} 3^{\mathrm{ab}}$ & $2.667^{\mathrm{a}}$ \\
\hline Superphosphate & $20.23^{a b}$ & $27.77^{\mathrm{bc}}$ & $\mathbf{3 0 . 3 3}^{\mathrm{abc}}$ & $2.667^{b c}$ & $2.667^{a b}$ & $3.000^{\mathrm{a}}$ \\
\hline Mycorrhiza & $19.97^{a b}$ & $\mathbf{3 3 . 3 0}^{\mathrm{a}}$ & $30.97^{\mathrm{abc}}$ & $2.333^{c}$ & $2.333^{a b}$ & $2.000^{\mathrm{b}}$ \\
\hline $\begin{array}{l}\text { Mycorrhiza + } \\
\text { Rhizobium } 10^{4}\end{array}$ & $20.33^{a b}$ & $24.53^{c}$ & $27.17^{\mathfrak{c}}$ & $\mathbf{3 . 3 3 3}^{\mathrm{ab}}$ & $2.333^{a b}$ & $2.667^{\mathrm{a}}$ \\
\hline $\begin{array}{l}\text { Mycorrhiza + } \\
\text { Rhizobium } 10^{8}\end{array}$ & $21.17^{\mathrm{a}}$ & $26.03^{c}$ & $31.47^{\mathrm{abc}}$ & $\mathbf{3 . 3 3 3}^{\mathrm{ab}}$ & $3.000^{\mathrm{a}}$ & $2.667^{\mathrm{a}}$ \\
\hline $\begin{array}{c}\text { Urea }+ \\
\text { Superphosphate }\end{array}$ & $18.93^{a b}$ & $28.77^{\mathrm{abc}}$ & $29.43^{b c}$ & $3.000^{\mathrm{abc}}$ & $2.667^{a b}$ & $2.000^{\mathrm{b}}$ \\
\hline Control & $19.63^{\mathrm{ab}}$ & $28.93^{\mathrm{abc}}$ & $29.67^{b c}$ & $3.000^{\text {abc }}$ & $2.000^{b}$ & $3.000^{\mathrm{a}}$ \\
\hline LSD & 3.088 & 5.174 & 5.401 & 0.9496 & 0.8319 & 0.5767 \\
\hline
\end{tabular}

- The same letters within each column are not significantly different at the 0.05 level of probability by the Duncan Multiple Range Test.

Effect of treatments on groundnut plant wet and dry weight at different sampling intervals (g/plant)

The results in table (2) clearly showed the effect of adding biological fertilizers; Mycorrhiza and Rhizobium positively affected the groundnut plant in terms of wet and dry weight, which 
International Journal of Agriculture and Environmental Research

ISSN: 2455-6939

Volume: 07, Issue: 03 "May-June 2021"

matched with the findings of (Howieson and Ballard, 2004) and (M.M., A., Hadad, M. A., \& Elhassan, 2016).

Table 2: Effect of treatments on groundnut plant wet and dry weight at different sampling intervals (g/plant).

\begin{tabular}{|c|c|c|c|c|c|c|}
\hline \multirow{2}{*}{$\begin{array}{c}\text { Ahmadi } \\
\text { Treatments }\end{array}$} & \multicolumn{3}{|c|}{ Plant wet weight $\mathrm{cm} /$ plant } & \multicolumn{3}{|c|}{ Plant dry weight $\mathrm{cm} /$ plant } \\
\hline & $\begin{array}{c}\text { (1) } \\
\text { Month }\end{array}$ & (2) Month & (3) Month & (1) Month & (2) Month & $\begin{array}{c}\text { (3) } \\
\text { Month }\end{array}$ \\
\hline Urea & $\mathbf{5 . 8 3 3}^{\mathrm{b}}$ & $41.13^{a b}$ & $78.77^{a b}$ & $1 . \mathbf{3 3 3}^{\mathrm{b}}$ & $10.67^{\mathrm{abc}}$ & $25.43^{\mathrm{a}}$ \\
\hline Rhizobium $10^{4}$ & $10.90^{\mathrm{a}}$ & $22.20^{b}$ & $94.33^{a b}$ & $2.633^{\mathrm{a}}$ & $8.100^{c}$ & 31.83 \\
\hline Rhizobium $10^{8}$ & $11.03^{a}$ & $32.17^{a b}$ & $146.7^{\mathrm{a}}$ & $2.503^{a b}$ & $19.90^{\mathrm{ab}}$ & $29.57^{\mathrm{a}}$ \\
\hline Superphosphate & $8.733^{\mathrm{ab}}$ & $28.70^{b}$ & $26.63^{b}$ & $1.933^{a b}$ & $9.767^{b c}$ & $24.63^{\mathrm{a}}$ \\
\hline Mycorrhiza & $8.067^{\mathrm{ab}}$ & $59.67^{\mathrm{a}}$ & $67.13^{\text {ab }}$ & $1.967^{\mathrm{ab}}$ & $22.27^{\mathrm{a}}$ & $31.60^{\mathrm{a}}$ \\
\hline $\begin{array}{l}\text { Mycorrhiza + } \\
\text { Rhizobium } 10^{4}\end{array}$ & $6.400^{a b}$ & $27.93^{b}$ & $52.00^{b}$ & $1.600^{\mathrm{ab}}$ & $8.300^{b c}$ & $20.03^{\mathrm{a}}$ \\
\hline $\begin{array}{l}\text { Mycorrhiza + } \\
\text { Rhizobium } 10^{8}\end{array}$ & $10.77^{a}$ & $36.23^{a b}$ & $105.4^{\mathrm{ab}}$ & $2.533^{a b}$ & $9.867^{b c}$ & $26.20^{\mathrm{a}}$ \\
\hline $\begin{array}{c}\text { Urea }+ \\
\text { Superphosphate }\end{array}$ & $6.900^{a b}$ & $23.23^{b}$ & $64.37^{a b}$ & $1.733^{a b}$ & $7.200^{c}$ & $21.73^{\mathrm{a}}$ \\
\hline Control & $8.200^{a b}$ & $36.03^{a b}$ & $88.23^{a b}$ & $1.967^{a b}$ & $11.03^{\text {abc }}$ & $28.17^{\mathrm{a}}$ \\
\hline LSD & 4.879 & 28.05 & 84.20 & 1.219 & 11.65 & 21.73 \\
\hline
\end{tabular}

- The same letters within each column are not significantly different at the 0.05 level of probability by the Duncan Multiple Range Test.

Effect of treatments on groundnuts number and weight of nodules in the primary roots

In the data presented in table (3), the nodulation was improved with the combination between Mycorrhiza and Rhizobium $\left(10^{8}\right)$ inoculum. The number and weight of nodules each plant improved with inoculation compared with the uninoculated pots and control, which agreed with the findings of (Howieson and Ballard, 2004), (Mmbaga et al., 2014) and (Ahiabor et al., 2014). 
International Journal of Agriculture and Environmental Research

ISSN: 2455-6939

Volume: 07, Issue: 03 "May-June 2021"

Table 3: Effect of treatments on groundnuts number and weight of nodules in primary roots

\begin{tabular}{|c|c|c|c|c|}
\hline \multirow{2}{*}{$\begin{array}{c}\text { Ahmadi treatments in } \\
\text { primary root }\end{array}$} & \multicolumn{2}{|c|}{ Second month } & \multicolumn{2}{|c|}{ Third month } \\
\hline & $\begin{array}{c}\text { Number of } \\
\text { nodules }\end{array}$ & Weight of nodules & $\begin{array}{c}\text { Number of } \\
\text { nodules }\end{array}$ & Weight of nodules \\
\hline Urea & $0.0000^{\mathrm{e}}$ & $0.0000^{\mathrm{e}}$ & $\mathbf{0 . 0 0 0 0}^{\mathrm{d}}$ & $\mathbf{0 . 0 0 0 0}^{\mathrm{d}}$ \\
\hline Rhizobium $10^{4}$ & $38.67^{d}$ & $0.1380^{\text {de }}$ & $59.67^{\text {bcd }}$ & $0.1449^{d}$ \\
\hline Rhizobium 10 ${ }^{8}$ & $47.67^{\text {bcd }}$ & $0.05490^{\mathrm{e}}$ & $81.67^{\mathrm{bc}}$ & $\mathbf{0 . 5 2 2 8}^{\mathrm{bcd}}$ \\
\hline Superphosphate & $0.0000^{\mathrm{e}}$ & $0.0000^{\mathrm{e}}$ & $\mathbf{0 . 0 0 0 0}^{\mathrm{d}}$ & $\mathbf{0 . 0 0 0 0}^{\mathrm{d}}$ \\
\hline Mycorrhiza & $0.0000^{\mathrm{e}}$ & $0.0000^{\mathrm{e}}$ & $0.0000^{d}$ & $\mathbf{0 . 0 0 0 0}^{\mathrm{d}}$ \\
\hline $\begin{array}{l}\text { Mycorrhiza + } \\
\text { Rhizobium } 10^{4}\end{array}$ & $59.33^{\text {ab }}$ & $0.4185^{b}$ & $34.67^{\text {cd }}$ & $\mathbf{0 . 1 1 4 3}^{\mathrm{d}}$ \\
\hline $\begin{array}{l}\text { Mycorrhiza + } \\
\text { Rhizobium } 10^{8}\end{array}$ & $58.33^{\text {ab }}$ & $\mathbf{0 . 6 0 8 3}^{\mathrm{a}}$ & $95.00^{\text {abc }}$ & $0.9298^{\text {abc }}$ \\
\hline Urea + Superphosphate & $0.0000^{\mathrm{e}}$ & $0.0000^{\mathrm{e}}$ & $\mathbf{0 . 0 0 0 0}^{\mathrm{d}}$ & $\mathbf{0 . 0 0 0 0}^{\mathrm{d}}$ \\
\hline Control & $0.6667^{\mathrm{e}}$ & $0.0004000^{\mathrm{e}}$ & $\mathbf{0 . 0 0 0 0}^{\mathrm{d}}$ & $\mathbf{0 . 0 0 0 0}^{\mathrm{d}}$ \\
\hline LSD & 10.18 & 0.1341 & 25.45 & 0.2189 \\
\hline
\end{tabular}

- The same letters within each column are not significantly different at the 0.05 level of probability by the Duncan Multiple Range Test.

\section{Effect of treatment on groundnut number and weight of nodules in lateral roots}

The results attached to table (4) showed that the formation of root nodules in the groundnut plant was significantly affected by the addition of the biological fertilizer, Mycorrhiza and Rhizobium in number and weight. This matched with (Howieson and Ballard, 2004) and (Mmbaga et al., 2014). 
International Journal of Agriculture and Environmental Research

ISSN: 2455-6939

Volume: 07, Issue: 03 "May-June 2021"

Table 4: Effect of treatment on groundnut number and weight of nodules in lateral roots

\begin{tabular}{|c|c|c|c|c|}
\hline \multirow{2}{*}{$\begin{array}{c}\text { Ahmadi treatments in } \\
\text { lateral root }\end{array}$} & \multicolumn{2}{|c|}{ Second month } & \multicolumn{2}{|c|}{ Third month } \\
\hline & $\begin{array}{c}\text { Number of } \\
\text { nodules }\end{array}$ & Weight of nodules & $\begin{array}{c}\text { Number of } \\
\text { nodules }\end{array}$ & Weight of nodules \\
\hline Urea & $19.67^{\mathrm{bcd}}$ & $0.02630^{c}$ & $0.0000^{\mathrm{c}}$ & $0.0000^{d}$ \\
\hline Rhizobium $10^{4}$ & $62.67^{\mathrm{a}}$ & $0.1211^{\text {bc }}$ & $54.00^{b c}$ & $0.1131^{d}$ \\
\hline Rhizobium $10^{8}$ & $60.33^{\mathrm{ab}}$ & $0.1809^{\text {bc }}$ & $100.7^{a b}$ & $0.3674^{\text {cd }}$ \\
\hline Superphosphate & $0.0000^{d}$ & $0.0000^{\mathrm{c}}$ & $0.0000^{\mathrm{c}}$ & $0.0000^{d}$ \\
\hline Mycorrhiza & $19.33^{\text {bcd }}$ & $0.05300^{c}$ & $0.0000^{\mathrm{c}}$ & $0.0000^{d}$ \\
\hline $\begin{array}{l}\text { Mycorrhiza + } \\
{\text { Rhizobium } 10^{4}}^{4}\end{array}$ & $49.33^{a b}$ & $0.1757^{b c}$ & $63.33^{b c}$ & $\mathbf{0 . 7 2 5 8}^{\mathrm{bc}}$ \\
\hline $\begin{array}{l}\text { Mycorrhiza + } \\
{\text { Rhizobium } 10^{8}}^{2}\end{array}$ & $60.00^{a b}$ & $0.3260^{b}$ & $105.3^{\text {ab }}$ & $1.078^{a b}$ \\
\hline Urea + Superphosphate & $0.0000^{d}$ & $0.0000^{c}$ & $0.0000^{\mathrm{c}}$ & $0.0000^{d}$ \\
\hline Control & $2.000^{c d}$ & $0.0012^{\mathrm{c}}$ & $0.0000^{\mathrm{c}}$ & $0.0000^{d}$ \\
\hline LSD & 56.73 & 0.2896 & 38.62 & 0.3238 \\
\hline
\end{tabular}

- The same letters within each column are not significantly different at the 0.05 level of probability by the Duncan Multiple Range Test.

Effect of local isolated Mycorrhiza, Rhizobium strains and fertilization on Ahmadi cultivar yield

The data in table (5) was erratic. A combination of factors may have influenced the effect of the treatment on the appearance of groundnut nodules. Despite that, the applied Rhizobiumstrain $10^{8}$ and the combination between Mycorrhiza and Rhizobium strain $10^{8}$ increased the yield of specific groundnut cultivars in the third month. This was described by (Ahiabor et al., 2014) and (Schütz et al., 2018). 
International Journal of Agriculture and Environmental Research

ISSN: 2455-6939

Volume: 07, Issue: 03 "May-June 2021"

Table 5: Effect of local isolated Mycorrhiza, Rhizobium strains and fertilization on Ahmadi cultivar yield

\begin{tabular}{|c|c|c|c|c|}
\hline \multirow[t]{2}{*}{ Ahmadi treatments } & \multicolumn{2}{|c|}{ Second month } & \multicolumn{2}{|c|}{ Third month } \\
\hline & Grain No. & Grain weight & Grain No. & Grain weight \\
\hline Urea & $6.333^{a b}$ & $\mathbf{3 . 3 3 3}^{\mathrm{b}}$ & $19.67^{b}$ & $25.63^{b}$ \\
\hline Rhizobium $10^{4}$ & $15.67^{a b}$ & $17.80^{\mathrm{a}}$ & $\mathbf{3 2 . 3 3}^{\mathrm{ab}}$ & $37.57^{\mathrm{ab}}$ \\
\hline Rhizobium $10^{8}$ & $8.333^{a b}$ & $5.100^{a b}$ & $47.33^{\mathrm{a}}$ & $61.57^{\mathrm{a}}$ \\
\hline Superphosphate & $18.67^{\mathrm{a}}$ & $13.63^{a b}$ & $26.00^{a b}$ & $17.27^{b}$ \\
\hline Mycorrhiza & $7.667^{a b}$ & $\mathbf{3 . 4 3 3}^{\mathrm{b}}$ & $29.00^{a b}$ & $22.53^{b}$ \\
\hline $\begin{array}{l}\text { Mycorrhiza + } \\
\text { Rhizobium } 10^{4}\end{array}$ & $6.000^{a b}$ & $5.833^{\text {ab }}$ & $18.67^{b}$ & $20.03^{b}$ \\
\hline $\begin{array}{l}\text { Mycorrhiza + } \\
\text { Rhizobium } 10^{8}\end{array}$ & $5.667^{b}$ & $4.167^{b}$ & $31.67^{a b}$ & $37.30^{\mathrm{ab}}$ \\
\hline Urea + Superphosphate & $4.229^{b}$ & $4.444^{b}$ & $19.00^{b}$ & $18.40^{b}$ \\
\hline Control & $\mathbf{5 . 3 3 3}^{\mathrm{b}}$ & $3.600^{b}$ & $28.33^{\text {ab }}$ & $24.07^{b}$ \\
\hline LSD & 12.68 & 13.32 & 26.26 & 34.36 \\
\hline
\end{tabular}

- The same letters within each column are not significantly different at the 0.05 level of probability by the Duncan Multiple Range Test.

Effect of isolated Mycorrhiza, Rhizobium strains and fertilization on Ahmadi cultivar content of $\mathbf{N}, \mathbf{P}$ and $\mathrm{K}$

Table (6) showed that treatment of Rhizobium $10^{4}, 10^{8}$, urea and combination between Rhizobium $10^{4}+$ Mycorrhiza and Rhizobium $10^{8}+$ Mycorrhiza significantly improved uptake of macroelements $(\mathrm{N}, \mathrm{K})$ compared with the uninoculated controls and other treatments. These results could be recognized as a Mycorrhizal positive infection that agreed with the findings of (M.M., A., Hadad, M. A., \& Elhassan, 2016). No significant differences were observed between treatments among the potassium content in groundnut plants. This agrees with the findings of (Howieson and Ballard, 2004) and (Osman and Abd Elaziz, 2010). 
International Journal of Agriculture and Environmental Research

ISSN: 2455-6939

Volume: 07, Issue: 03 "May-June 2021"

Table 6: Effect of isolated Mycorrhiza, Rhizobium strains and fertilization on Ahmadi cultivar content of $\mathbf{N}, \mathbf{P}$ and $\mathrm{K}$

\begin{tabular}{|c|c|c|c|}
\hline Treatments & $\mathrm{N \%}$ & $\mathbf{P \%}$ & $\mathbf{K} \%$ \\
\hline Urea & $\mathbf{3 . 5 3 3}^{\mathrm{ab}}$ & $0.2333^{\mathrm{e}}$ & $0.2333^{a b}$ \\
\hline Rhizobium $10^{4}$ & $3.567^{a}$ & $0.2667^{\mathrm{e}}$ & $0.2667^{\mathrm{ab}}$ \\
\hline Rhizobium 10 & $\mathbf{3 . 5 3 3}^{\mathrm{ab}}$ & $0.2000^{\text {ef }}$ & $0.1333^{\text {cd }}$ \\
\hline Superphosphate & $1.733^{\mathrm{d}}$ & $0.4333^{\text {cd }}$ & $\mathbf{0 . 1 3 3 3}^{\mathrm{cd}}$ \\
\hline Mycorrhiza & $1.500^{\mathrm{e}}$ & $0.3667^{d}$ & $0.2000^{b c}$ \\
\hline Mycorrhiza + Rhizobium $10^{4}$ & $3.333^{b}$ & $\mathbf{0 . 7 3 3 3}^{\mathrm{b}}$ & $0.3000^{\mathrm{a}}$ \\
\hline Mycorrhiza + Rhizobium $10^{8}$ & $3.400^{\mathrm{ab}}$ & $\mathbf{0 . 8 3 3 3}^{\mathrm{a}}$ & $0.2000^{b c}$ \\
\hline Urea + Superphosphate & $2.600^{c}$ & $0.5000^{c}$ & $0.1000 d^{e}$ \\
\hline Control & $1.100^{f}$ & $\mathbf{0 . 1 3 3 3}^{\mathrm{f}}$ & $0.02422^{\mathrm{e}}$ \\
\hline LSD & 0.2048 & 0.07741 & 0.07741 \\
\hline
\end{tabular}

- The same letters within each column are not significantly different at the 0.05 level of probability by the Duncan Multiple Range Test.

\section{M383 cultivar:}

\section{Effect of treatments on plant height and colour rating}

The results in table (7) showed no significant differences in terms of colour rating. As for the height of the plant, it was found that the addition of mineral fertilizers, especially superphosphate and the addition of Rhizobium and Mycorrhiza, had a significant effect on the height of the plant, which agreed with the findings of (Mmbaga et al., 2014), (Ahiabor et al., 2014) and (M.M., A., Hadad, M. A., \& Elhassan, 2016). 
International Journal of Agriculture and Environmental Research

ISSN: 2455-6939

Volume: 07, Issue: 03 "May-June 2021"

Table 7: Effect of treatments on plant height and colour rating

\begin{tabular}{|c|c|c|c|c|c|c|}
\hline \multirow{2}{*}{$\begin{array}{c}\text { M383 } \\
\text { Treatments }\end{array}$} & \multicolumn{3}{|c|}{ Plant height $\mathrm{cm} /$ plant } & \multicolumn{3}{|c|}{ Colour rating } \\
\hline & $\begin{array}{c}\text { (1) } \\
\text { Month }\end{array}$ & (2) Month & (3) Month & (1) Month & (2) Month & $\begin{array}{c}\text { (3) } \\
\text { Month }\end{array}$ \\
\hline Urea & $19.10^{b}$ & $29.00^{b c}$ & $33.43^{\mathrm{a}}$ & $4.000^{a}$ & $4.000^{a}$ & $3.000^{c}$ \\
\hline Rhizobium $10^{4}$ & $22.30^{\mathrm{a}}$ & $33.20^{a b}$ & $34.13^{a}$ & $\mathbf{3 . 3 3 3}^{\mathrm{ab}}$ & $4.000^{a}$ & $\mathbf{3 . 3 3 3}^{\mathrm{bc}}$ \\
\hline Rhizobium $10^{8}$ & $20.00^{a b}$ & $35.33^{\mathrm{a}}$ & $30.10^{a b}$ & $3.667^{\text {ab }}$ & $4.000^{a}$ & $3.000^{c}$ \\
\hline Superphosphate & $22.37^{a}$ & $30.33^{\text {abc }}$ & $35.57^{a}$ & $4.000^{a}$ & $4.000^{a}$ & $3.333^{b c}$ \\
\hline Mycorrhiza & $18.67^{b}$ & $30.97^{\mathrm{abc}}$ & $32.00^{a}$ & $4.000^{a}$ & $4.000^{a}$ & $3.667^{\mathrm{ab}}$ \\
\hline $\begin{array}{l}\text { Mycorrhiza + } \\
\text { Rhizobium } 10^{4}\end{array}$ & $18.27^{b}$ & $27.17^{\mathrm{c}}$ & $34.87^{a}$ & $3.000^{b}$ & $4.000^{a}$ & $\mathbf{3 . 3 3 3}^{\mathrm{bc}}$ \\
\hline 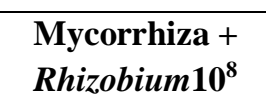 & $20.80^{a b}$ & $31.47^{\mathrm{abc}}$ & $29.33^{a b}$ & $3.667^{\text {ab }}$ & $3.667^{\mathrm{ab}}$ & $3.000^{c}$ \\
\hline $\begin{array}{c}\text { Urea }+ \\
\text { Superphosphate }\end{array}$ & $19.17^{b}$ & $29.43^{b c}$ & $25.00^{b}$ & $\mathbf{3 . 3 3 3}^{\mathrm{ab}}$ & $3.667^{a b}$ & $3.000^{c}$ \\
\hline Control & $18.57^{b}$ & $29.67^{b c}$ & $\mathbf{3 1 . 9 3}^{\mathrm{a}}$ & $\mathbf{3 . 3 3 3}^{\mathrm{ab}}$ & $\mathbf{3 . 3 3 3}^{\mathrm{b}}$ & $4.000^{\mathrm{a}}$ \\
\hline LSD & 3.103 & 5.401 & 6.271 & 0.7262 & 0.5635 & 0.6659 \\
\hline
\end{tabular}

- The same letters within each column are not significantly different at the 0.05 level of probability by the Duncan Multiple Range Test.

Effect of the treatments on groundnut plant wet and dry weight at different sampling intervals $(g /$ plant $)$

The results in table (8) showed that the addition of mineral fertilizers and biofertilizers, Rhizobium, and Mycorrhiza, led to a remarkable increase in the wet weight of the plant. The results also showed that the addition of mineral fertilizers, urea and superphosphate, had a more significant effect than the biofertilizers. Concerning the dry weight of the plant, this matched with the findings of Mahdi et al., (2004) and Alsamowal et al., (2016). 
International Journal of Agriculture and Environmental Research

ISSN: 2455-6939

Volume: 07, Issue: 03 "May-June 2021"

Table 8: Effect of the treatments on groundnut plant wet and dry weight

\begin{tabular}{|c|c|c|c|c|c|c|}
\hline \multirow{2}{*}{$\begin{array}{c}\text { M383 } \\
\text { Treatments }\end{array}$} & \multicolumn{3}{|c|}{ Plant wet weight $\mathrm{cm} /$ plant } & \multicolumn{3}{|c|}{ Plant dry weight $\mathrm{cm} /$ plant } \\
\hline & $\begin{array}{c}\text { (1) } \\
\text { Month }\end{array}$ & (2) Month & (3) Month & (1) Month & (2) Month & $\begin{array}{c}\text { (3) } \\
\text { Month }\end{array}$ \\
\hline Urea & $6.933^{\text {bc }}$ & $71.80^{a}$ & $96.03^{a b}$ & $\mathbf{1 . 9 3 3}^{\mathrm{b}}$ & $15.37^{\mathrm{ab}}$ & $34.30^{\mathrm{a}}$ \\
\hline Rhizobium $10^{4}$ & $11.47^{\mathrm{a}}$ & $28.70^{b}$ & $100.9^{a b}$ & $\mathbf{3 . 0 3 3}^{\mathrm{a}}$ & $6.733^{b}$ & $34.13^{a}$ \\
\hline Rhizobium $10^{8}$ & $7.700^{b c}$ & $43.07^{a b}$ & $80.17^{\text {ab }}$ & $2.067^{\text {ab }}$ & $10.80^{a b}$ & $25.90^{\mathrm{ab}}$ \\
\hline Superphosphate & $6.400^{b c}$ & $29.93^{b}$ & $39.97^{\mathrm{ab}}$ & $1.800^{\mathrm{bc}}$ & $8.900^{\mathrm{ab}}$ & $37.83^{a}$ \\
\hline Mycorrhiza & $6.800^{b c}$ & $74.97^{\mathrm{a}}$ & $\mathbf{3 2 . 0 3}^{\mathrm{b}}$ & $1.833^{\text {bc }}$ & $22.17^{\mathrm{a}}$ & $31.83^{a}$ \\
\hline $\begin{array}{l}\text { Mycorrhiza + } \\
\text { Rhizobium } 10^{4}\end{array}$ & $7.500^{b c}$ & $42.20^{a b}$ & $109.2^{\mathrm{a}}$ & $\mathbf{1 . 9 3 3}^{\mathrm{b}}$ & $12.30^{a b}$ & $31.50^{\mathrm{ab}}$ \\
\hline 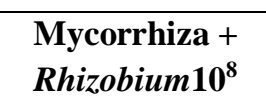 & $9.600^{\mathrm{ab}}$ & $35.27^{\mathrm{ab}}$ & $92.33^{\text {ab }}$ & $1.900^{b}$ & $10.90^{a b}$ & $28.13^{\text {ab }}$ \\
\hline $\begin{array}{c}\text { Urea }+ \\
\text { Superphosphate }\end{array}$ & $4.833^{c}$ & $18.87^{b}$ & $35.30^{b}$ & $1.333^{\mathrm{bc}}$ & $6.167^{b}$ & $13.17^{b}$ \\
\hline Control & $5.133^{\mathrm{c}}$ & $19.20^{b}$ & $77.00^{a b}$ & $0.8000^{\mathrm{c}}$ & $10.73^{a b}$ & $24.93^{\text {ab }}$ \\
\hline LSD & $\mathbf{3 . 6 3 4}$ & 40.01 & 69.32 & 1.085 & 13.29 & 18.47 \\
\hline
\end{tabular}

- The same letters within each column are not significantly different at the 0.05 level of probability by the Duncan Multiple Range Test.

Effect of treatment on groundnuts number and weight of nodules in primary roots in M383 cultivar

The data in the table (9) showed that adding Rhizobium strains $10^{4}, 10^{8}$ as a single fertilizer and combination between Rhizobium and Mycorrhiza significantly improved both the number and mass of nodulation in both primary and lateral roots, also observed no significant differences between other treatments. This agreed with the findings of Mahdi et al., (2004), Ahiabor et al., (2014) and Schütz et al., (2018). 
International Journal of Agriculture and Environmental Research

ISSN: 2455-6939

Volume: 07, Issue: 03 "May-June 2021"

Table 9: Effect of treatment on groundnuts number and weight of nodules in primary roots

\begin{tabular}{|c|c|c|c|c|}
\hline M383 & \multicolumn{2}{|c|}{ Second month } & \multicolumn{2}{|c|}{ Third month } \\
\hline $\begin{array}{l}\text { Treatments } \\
\text { primary root }\end{array}$ & $\begin{array}{l}\text { Number of } \\
\text { nodules }\end{array}$ & Weight of nodules & $\begin{array}{c}\text { Number of } \\
\text { nodules }\end{array}$ & Weight of nodules \\
\hline Urea & $0.0000^{\mathrm{e}}$ & $0.0000^{\mathrm{e}}$ & $0.0000^{d}$ & $\mathbf{0 . 0 0 0 0}^{\mathrm{d}}$ \\
\hline Rhizobium 10 & $\mathbf{5 5 . 0 0}^{\text {abc }}$ & $0.03627^{\mathrm{e}}$ & $111.7^{a b}$ & $\mathbf{1 . 0 8 8}^{\mathrm{ab}}$ \\
\hline Rhizobium $10^{8}$ & $45.67^{\text {cd }}$ & $\mathbf{0 . 0 3 3 8 3}^{\mathrm{e}}$ & $85.67^{b c}$ & $0.3727^{\text {cd }}$ \\
\hline Superphosphate & $0.0000^{\mathrm{e}}$ & $0.0000^{\mathrm{e}}$ & $0.0000^{d}$ & $0.0000^{d}$ \\
\hline Mycorrhiza & $0.0000^{\mathrm{e}}$ & $0.0000^{\mathrm{e}}$ & $0.0000^{d}$ & $0.0000^{d}$ \\
\hline $\begin{array}{l}\text { Mycorrhiza + } \\
\text { Rhizobium } 10^{4}\end{array}$ & $66.33^{\mathrm{a}}$ & $0.2500^{\mathrm{cd}}$ & $156.0^{\mathrm{a}}$ & $1.233^{\mathrm{a}}$ \\
\hline $\begin{array}{l}\text { Mycorrhiza + } \\
{\text { Rhizobium } 10^{8}}^{8}\end{array}$ & $56.00^{\text {abc }}$ & $0.3607^{b c}$ & $102.0^{\mathrm{ab}}$ & $0.1132^{d}$ \\
\hline Urea + Superphosphate & $\mathbf{0 . 0 0 0 0}^{\mathrm{e}}$ & $\mathbf{0 . 0 0 0 0}^{\mathrm{e}}$ & ${0.0000^{d}}^{d}$ & $\mathbf{0 . 0 0 0 0}^{\mathrm{d}}$ \\
\hline Control & $\mathbf{0 . 3 3 3 3}^{\mathrm{e}}$ & $0.0000^{\mathrm{e}}$ & $0.0000^{d}$ & $0.0000^{d}$ \\
\hline LSD & 10.67 & 0.1224 & 80.26 & 0.8860 \\
\hline
\end{tabular}

- The same letters within each column are not significantly different at the 0.05 level of probability by the Duncan Multiple Range Test.

Effect of treatment on groundnuts number and weight of nodules in lateral roots in M383 cultivar

The results in the table (10) showed that the addition of the mixture of Rhizobium and Mycorrhiza had a positive effect on the groundnut plant M383 cultivar, in agreement with Mahdi et al., (2004) and Alsamowal et al., (2016). 
International Journal of Agriculture and Environmental Research

ISSN: 2455-6939

Volume: 07, Issue: 03 "May-June 2021"

Table 10: Effect of treatment on groundnuts number and weight of nodules in lateral roots

\begin{tabular}{|c|c|c|c|c|}
\hline M383 & \multicolumn{2}{|c|}{ Second month } & \multicolumn{2}{|c|}{ Third month } \\
\hline $\begin{array}{l}\text { treatments } \\
\text { lateral root }\end{array}$ & $\begin{array}{c}\text { Number of } \\
\text { nodules }\end{array}$ & $\begin{array}{c}\text { Weight of } \\
\text { nodules }\end{array}$ & $\begin{array}{c}\text { Number of } \\
\text { nodules }\end{array}$ & $\begin{array}{c}\text { Weight of } \\
\text { nodules }\end{array}$ \\
\hline Urea & $0.0000^{d}$ & $0.0000^{\mathrm{c}}$ & $0.0000^{d}$ & $25.00^{\mathrm{abc}}$ \\
\hline Rhizobium $10^{4}$ & $44.33^{\mathrm{abc}}$ & $\mathbf{0 . 0 3 5 4 3}^{\mathrm{c}}$ & $0.3134^{\text {cd }}$ & $41.67^{\mathrm{ab}}$ \\
\hline Rhizobium $10^{8}$ & $42.00^{\text {abcd }}$ & $0.02810^{c}$ & $0.5608^{\text {bcd }}$ & $26.33^{\mathrm{abc}}$ \\
\hline Superphosphate & $0.0000^{d}$ & $0.0000^{\mathrm{c}}$ & $0.0000^{d}$ & $\mathbf{3 6 . 0 0}^{\mathrm{abc}}$ \\
\hline Mycorrhiza & $0.0000^{d}$ & $0.0000^{\mathrm{c}}$ & $0.0000^{d}$ & $35.00^{\mathrm{abc}}$ \\
\hline $\begin{array}{l}\text { Mycorrhiza + } \\
\text { Rhizobium 10 }\end{array}$ & $\mathbf{5 2 . 3 3}^{\mathrm{ab}}$ & $0.09050^{c}$ & $1.484^{a}$ & $27.00^{\mathrm{abc}}$ \\
\hline 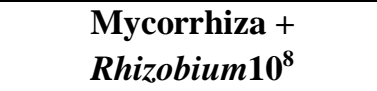 & $75.33^{a}$ & $0.7640^{\mathrm{a}}$ & $0.7427^{b c}$ & $28.33^{\text {abc }}$ \\
\hline Urea + Superphosphate & $2.000^{\text {cd }}$ & $0.0000^{\mathrm{c}}$ & $0.0000^{d}$ & $14.33^{c}$ \\
\hline Control & $0.0000^{d}$ & $0.0000^{c}$ & $0.0000^{c}$ & $0.0000^{d}$ \\
\hline LSD & 14.89 & 0.05474 & 87.01 & 0.7116 \\
\hline
\end{tabular}

- The same letters within each column are not significantly different at the 0.05 level of probability by the Duncan Multiple Range Test.

Effect of local isolated Mycorrhiza, Rhizobium strains and fertilization on M383 cultivar yield

Table (11) showed no response to adding the different fertilizers in the first month. The plant response to added fertilizers was evident in the third month, which was affected by yield increase when the combination of rhizobium and Mycorrhiza treatment matching with Alsamowal et al., (2016) and Schütz et al., (2018). 
International Journal of Agriculture and Environmental Research

ISSN: 2455-6939

Volume: 07, Issue: 03 "May-June 2021"

\begin{abstract}
Table 11: Effect of local isolated Mycorrhiza, Rhizobium strains and fertilization on M383 cultivar yield
\end{abstract}

\begin{tabular}{|c|c|c|c|c|}
\hline \multirow{2}{*}{$\begin{array}{c}\text { M383 } \\
\text { Treatments }\end{array}$} & \multicolumn{2}{|c|}{ Second month } & \multicolumn{2}{|c|}{ Third month } \\
\hline & Grain No. & Grain weight & Grain No. & Grain weight \\
\hline Urea & $11.40^{\mathrm{a}}$ & $1.000^{a b}$ & $25.00^{\text {abc }}$ & $29.87^{\text {abc }}$ \\
\hline Rhizobium $10^{4}$ & $4.400^{a}$ & $1.667^{\mathrm{a}}$ & $41.67^{\mathrm{ab}}$ & $44.40^{a b}$ \\
\hline Rhizobium10 ${ }^{8}$ & $5.033^{a}$ & $1.333^{a b}$ & $26.33^{\text {abc }}$ & $27.87^{\text {abc }}$ \\
\hline Superphosphate & $6.000^{a}$ & $1.000^{a b}$ & $36.00^{\text {abc }}$ & $20.43^{\text {bc }}$ \\
\hline Mycorrhiza & $17.97^{\mathrm{a}}$ & $1.000^{a b}$ & $35.00^{\text {abc }}$ & $23.23^{\text {bc }}$ \\
\hline $\begin{array}{l}\text { Mycorrhiza + } \\
\text { Rhizobium } 10^{4}\end{array}$ & $8.633^{a}$ & $1.333^{a b}$ & $27.00^{\text {abc }}$ & $\mathbf{3 5 . 3 3}^{\mathrm{abc}}$ \\
\hline $\begin{array}{l}\text { Mycorrhiza + } \\
\text { Rhizobium } 10^{8}\end{array}$ & $7.800^{\mathrm{a}}$ & $1.333^{a b}$ & $28.33^{\text {abc }}$ & $\mathbf{3 2 . 5 3}^{\mathrm{abc}}$ \\
\hline Urea + Superphosphate & $3.367^{\mathrm{a}}$ & $1.000^{a b}$ & $14.33^{c}$ & $8.567^{c}$ \\
\hline Control & $11.33^{\text {abc }}$ & $9.667^{\mathrm{a}}$ & $16.00^{c}$ & $19.73^{\text {bc }}$ \\
\hline LSD & 12.26 & 14.86 & 15.77 & 23.44 \\
\hline
\end{tabular}

- The same letters within each column are not significantly different at the 0.05 level of probability by the Duncan Multiple Range Test.

Effect of isolated Mycorrhiza, Rhizobium strains and fertilization on M383 cultivar content of $\mathbf{N}, \mathbf{P}$ and $\mathrm{K}$

The results represented in table (12), Addition of Rhizobium and Mycorrhiza separately in combination between Rhizobium $10^{4}+$ Mycorrhiza and Rhizobium $10^{8}+$ Mycorrhiza treatments improved the capacity of the plant to acquire nutrientsand significantly improved uptake of macro elements $(\mathrm{N}, \mathrm{P}, \mathrm{K})$ compared to the control and other treatments. These results could be attributed to Mycorrhiza positive infection which was matching with Elhassan et al., (2010). 
International Journal of Agriculture and Environmental Research

ISSN: 2455-6939

Volume: 07, Issue: 03 "May-June 2021"

Table 12: Effect of isolated Mycorrhiza, Rhizobium strains and fertilization on $M 383$ cultivar content of $N, P$ and $K$

\begin{tabular}{|c|c|c|c|}
\hline Treatments & N\% & P\% & $\mathrm{K} \%$ \\
\hline Urea & $2.467^{b c}$ & $0.2333^{\mathrm{c}}$ & $\mathbf{0 . 3 3 3 3}^{\mathrm{a}}$ \\
\hline Rhizobium $10^{4}$ & $2.400^{c}$ & $0.1667^{\mathrm{cd}}$ & $0.3000^{\mathrm{ab}}$ \\
\hline Rhizobium $10^{8}$ & $1.667^{d}$ & $0.4667^{d}$ & $0.2333^{\text {bc }}$ \\
\hline Superphosphate & $1.400^{\mathrm{e}}$ & $0.4000^{b}$ & $0.1667^{\mathrm{cd}}$ \\
\hline Mycorrhiza & $3.400^{\mathrm{a}}$ & $\mathbf{0 . 7 3 3 3}^{\mathrm{a}}$ & $\mathbf{0 . 1 3 3 3}^{\mathrm{d}}$ \\
\hline $\begin{array}{l}\text { Mycorrhiza + } \\
\text { Rhizobium } 10^{4}\end{array}$ & $3.400^{\mathrm{a}}$ & $0.6667^{\mathrm{a}}$ & $0.2333^{b c}$ \\
\hline 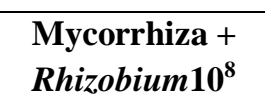 & $2.667^{b}$ & $0.4667^{b}$ & $0.2667^{a b}$ \\
\hline $\begin{array}{c}\text { Urea }+ \\
\text { Superphosphate }\end{array}$ & $\mathbf{1 . 0 3 3}^{\mathrm{f}}$ & $0.1000^{\text {cd }}$ & $\mathbf{0 . 1 3 3 3}^{\mathrm{d}}$ \\
\hline Control & $0.07876^{\mathrm{g}}$ & $\mathbf{0 . 0 4 9 5 3}^{\mathrm{d}}$ & $0.1000^{d}$ \\
\hline LSD & 0.2386 & 0.1448 & 0.094810 \\
\hline
\end{tabular}

- Means with the same letters within each column are not significantly different at the 0.05 level of probability by the Duncan Multiple Range Test

\section{REFERENCES}

Ahiabor, B.D.K., Lamptey, S., Yeboah, S., Bahari, V., 2014. Application of phosphorus fertilizer on soybean [(Glycine max L.(Merril)] inoculated with rhizobium and its economic implication to farmers. J. Exp. Agric. Int. 1420-1434.

Ahmed, B., Echekwu, C.A., Mohammed, S.G., Ojiewo, C., Ajeigbe, H., Vabi, M.B., Affognon, H., Lokossou, J., Nwahia, O.C., 2020. Analysis of Adoption of Improved Groundnut Varieties in the Tropical Legume Project (TL III) States in Nigeria. Agric. Sci. 11, 143.

Albareda, M., Rodríguez-Navarro, D.N., Temprano, F.J., 2009. Soybean inoculation: Dose, N fertilizer supplementation and rhizobia persistence in soil. F. Crop. Res. 113, 352-356. 
International Journal of Agriculture and Environmental Research

ISSN: 2455-6939

Volume: 07, Issue: 03 "May-June 2021"

Amba, A.A., Agbo, E.B., Garba, A., 2013. Effect of nitrogen and phosphorus fertilizers on nodulation of some selected grain legumes at Bauchi, Northern Guinea Savanna of Nigeria. Int. J. Biosci 3, 1-7.

El Naim, A.M., Ahmed, S.E., 2010. Effect of weeding frequencies on growth and yield of two roselle (Hibiscus sabdariffa L) varieties under rain fed. Aust. J. Basic Appl. Sci. 4, 42504255 .

Gerdemann, J.W., Nicolson, T.H., 1963. Spores of mycorrhizal Endogone species extracted from soil by wet sieving and decanting. Trans. Br. Mycol. Soc. 46, 235-244.

Harter, H.L., 1960. Critical values for Duncan's new multiple range test. Biometrics 671-685.

Howieson, J., Ballard, R., 2004. Optimising the legume symbiosis in stressful and competitive environments within southern Australia-some contemporary thoughts. Soil Biol. Biochem. 36, 1261-1273.

Htwe, A.Z., Moh, S.M., Soe, K.M., Moe, K., Yamakawa, T., 2019. Effects of biofertilizer produced from Bradyrhizobium and Streptomyces griseoflavus on plant growth, nodulation, nitrogen fixation, nutrient uptake, and seed yield of mung bean, cowpea, and soybean. Agronomy 9, 77.

Kızılkaya, R., 2008. Yield response and nitrogen concentrations of spring wheat (Triticum aestivum) inoculated with Azotobacter chroococcum strains. Ecol. Eng. 33, 150-156.

M.M., A., Hadad, M. A., \& Elhassan, G.., 2016. No Title The effect of local mycorrhiza isolated, Rhizobium and fertilization on zea mays and groundnuts plant productivity under field condition in Sudan. J. Agric. Res. 2(3), 26-42.

Mmbaga, G.W., Mtei, K.M., Ndakidemi, P.A., 2014. Extrapolations on the use of rhizobium inoculants supplemented with phosphorus $(\mathrm{P})$ and potassium $(\mathrm{K})$ on growth and nutrition of legumes. Agric. Sci. 5, 1207.

Osman, A.G., Abd Elaziz, F.I., 2010. Effects of biological and mineral fertilization on nodulation, nitrogen and phosphorus content and yield of faba bean (Vicia faba L.) cultivar seleim. Adv. Environ. Biol. 86-95.

Ryan, J., Garabet, S., Harmsen, K., Rashid, A., 1996. A soil and plant analysis manual adapted for the West Asia and North Africa region. ICARDA, Aleppo, Syria 140. 
International Journal of Agriculture and Environmental Research

ISSN: 2455-6939

Volume: 07, Issue: 03 "May-June 2021"

Schütz, L., Gattinger, A., Meier, M., Müller, A., Boller, T., Mäder, P., Mathimaran, N., 2018. Improving crop yield and nutrient use efficiency via biofertilization-A global metaanalysis. Front. Plant Sci. 8, 2204.

Taru, V.B., Kyagya, I.Z., Mshelia, S.I., 2010. Profitability of groundnut production in Michika local government area of Adamawa state, Nigeria. J. Agric. Sci. 1, 25-29.

Albareda, M., D.N. Rodriguez-Navarro and F.J. Temprano, 2009. Soybean inoculation: Dose, N fertilizer supplementation and rhizobia persistence in soil. Field Crops Res., 113: 352356.

Alsamowal M.M., M. A. Hadad and G.A.Elhassan,(2016). The effect of local mycorrhiza isolated, Rhizobium and fertilization on zea mays and groundnuts plant productivity under field condition in Sudan. Journal of Agricultural and Research,Vol no 2 Issue 3 March 2016, ISSN: 2455-7668.

Amba, A.A., E.B. Agbo and A. Garba, 2013. Effect of nitrogen and phosphorus fertilizers on nodulation of some selected grain legumes at Bauchi, Northern Guinea Savanna of Nigeria. Int. J. Biosci., 3: 1-7.

B. Ahiabor, S. Lamptey, S. Yeboah, and V. Bahari, "Application of phosphorus fertilizer on soybean [(Glycine max L. (Merril)] inoculated with rhizobium and its economic implication to farmers," American Journal of Experimental Agriculture, vol. 4, no. 11, pp. 1420-1434, 2014.

CGIAR (2004-2005) Research \& Impact: Areas of Research: Groundnut.http://www.cgiar.org/impact/research/groundnut.html. CGIAR 2004-2005.

Duncan, B.O. (1955). Multiple Range test and Multiple F - test .Biometrics 11: 1-42.

Elhassan, A. G., M. E. Abdelgani, A. G. Osman, S. S. Mohamed and Belgees S. Abdelgadir (2010) Potential Production and Application of Biofertilizers in Sudan, p1,2.

El-Naim AM, Ahmed SE. Effect of weeding frequencies on growth and yield of two roselle (Hibiscus sabdariffa L.) varieties under rain fed. Australian Journal of Basic and Applied Sciences. 2010;4(9):4250-4255.

G. W. Mmbaga, K. M. Mtei, and P. A. Ndakidemi, "Extrapolations on the use of rhizobium inoculants supplemented with phosphorus $(\mathrm{P})$ and potassium $(\mathrm{K})$ on growth and nutrition of legumes,” Agricultural Sciences, vol. 5, no. 12, pp. 1207-1226, 2014. 
Gerdemann, J. W., and T. H. Niclson, (1963). Spores of mycorrhizal Endogone species extracted from soil by wet sieving and decanting. Trans. Br. Mycol.Soc., 46:235-244.

Howieson, J. and R. Ballard, (2004). Optimising the legume symbiosis in stressful and competitive environments within southern Australia - some contemporary thoughts. Soil Biology and Biochemistry 36: 1261-1273.

Htwe, Aung Zaw; Moh, Seinn Moh; Soe, Khin Myat; Moe, Kyi; Yamakawa, Takeo (February 2019). "Effects of Biofertilizer Produced from Brady Rhizobium and Streptomyces griseoflavus on Plant Growth, Nodulation, Nitrogen Fixation, Nutrient Uptake, and Seed Yield of Mung Bean, Cowpea, and Soybean". Agronomy. 9 (2): 77. doi:10.3390/agronomy9020077.

Kizilkaya, R. Yield response and nitrogen concentrations of spring wheat (Triticum aestivum) inoculated with Azotobacter chroococcum strains. Volume 33, Issue 2, 3 June 2008.

Mahdi, A. A., A. B. NurEldaim and A. A. Arbab. (2004). Influence of mycorrhizal inoculation form of phosphate fertilization and watering regime on nodulation and yield of soybean. U.K. J. Agric. Sci., 12: 345-356.

Ryan, J. S., G. K. Hannsen, and A. Rashid, (1996). A Soil and Plant Analysis Manual Adapted for the West Asia and North Africa Region. ICARDA, Aleppo, Syria. 140 pp.

Schütz, L., Gattinger, A., Meier, M., Müller, A., Boller, T., Mäder, P Mathimaran, N.,(2018). Improving Crop Yield and Nutrient Use Efficiency via Biofertilization-A Global Metaanalysis. Frontiers in Plant Science, vol no 8, ISSN:1664-462.

Taru VB, Kyagya IZ, Mshelia SI(2010). Profitability of Groundnut Production in Michika Local Government Area of Adamawa State, Nigeria. J.Agric. Sci.; 1(1):25-29. 